\title{
COURSE OF TEMPERATURES AND HUMIDITY OF THE AIR IN A LARGE-SCALE BARN FOR HEIFER REARING DURING THE SUMMER
}

\author{
A. FIŠER and Jana HÁJKOVÁ \\ Department of Prevention of Swine Diseases, Animal Breeding and Animals Hygiene, \\ University of Veterinary Science, 61242 Brno
}

Received March 30, 1989

\begin{abstract}
Fišer A., Hájková Jana: Course of Temperatures and Humidity of the Air in a Large-scale Barn for Heifer Rearing during the Summer. Acta vet. Brno, 59, 1990: 73-85.
\end{abstract}

In the present study of the course of temperatures and humidity of the air in a large-scale barn for heifer rearing, three macroclimatic situations were studied from May to September 1986. The macroclimatic situations are characterized as cold and rainy summer period, pleasant and warm summer period, and hot summer period.

In analyses of the three selected macroclimatic situations, the simultaneous effect of temperature and humidity of air in the barn on the housed animals was studied and was expressed as cold, the optimum temperature and humidity, and sultriness. The interrelationships between the outside temperature and humidity and those inside the barn are illustrated in graphs as the so-called average day of the period investigated.

The results have shown that a sultry atmosphere is brought about when the outside temperatures reach $17.95{ }^{\circ} \mathrm{C}$ and occurs in $51.52 \%$ (and/or $78.12 \%$ ) of the period of housing the animals in the barn. The relationship between the temperature and humidity was optimal in $78.72 \%$ (and/or $93.88 \%$ ) when the average outside air temperature was $10.90^{\circ} \mathrm{C}$; when it was $22.01{ }^{\circ} \mathrm{C}$, a permanent sultry atmosphere was observed in $52.34 \%$ (and/or $58.82 \%$ ) of the period of housing the animals in the barn.

The dependence on temperature and humidity of the outside air was the greatest during the hot summer period when the average temperature was $22.01{ }^{\circ} \mathrm{C}$ and relative humidity $63.30 \%$; this correlating dependence was statistically highly significant. In the other two macroclimatic situations, i.e. average temperatures $17.95^{\circ} \mathrm{C}$ and $10.90^{\circ} \mathrm{C}$, the similarity of the course of curves for temperature and humidity is more expressive only for temperature. Correlation between the ambient temperature of the barn and of the atmospheric outside air was highly significant only during pleasant summer weather in the back half of the barn when the average diurnal temperature reached $17.95^{\circ} \mathrm{C}$.

The course of the curve of humidity inside the barn is not always similar to that of the outside air. This is connected with ventilation of the front and back halves of the barn, or with the method of removing sources of water vapours, i.e. liquid manure, urine and technological water in the barn.

Bioclimate, technology of litter-free housing, temperature, humidity, pressure of water vapours in barn air

The course of temperature and humidity of air results from the production and losses of heat and water vapours in the barn. Heat is usually produced by the housed animals, while the production of water vapours results also from the evaporation of water associated with technological processes during feeding, or when removing excrements, depending on the technology of housing 
of the animals. Semenjuta et al. (1986) proved that the production of heat and gases was dependent on the growth rate. However, heat production is not proportional to the increase in body mass. In calves, after birth until 12 months of age, the body mass increases 13 times and heat production only 8 times. During autumn and winter, heat production of the calves was the highest, in summer, however, it was lover, and during spring it was the lowest. Statistically no significant differences were observed between the production of heat and of carbon dioxide in cows and heifers of the same body mass. Heat production increased when the air temperature increased above $10^{\circ} \mathrm{C}$, while it decreased when the temperature was lower then $10^{\circ} \mathrm{C}$.

European breeds of cattle are known to tolerate cold better than heat. The thermal comfort zone ranges between $1{ }^{\circ} \mathrm{C}$ and $24^{\circ} \mathrm{C}$. The critical temperature when the animals decrease their production, ranges between $21.0^{\circ} \mathrm{C}$ and $26.5^{\circ} \mathrm{C}$ in most breeds of cattle in Europe (Sainsbury 1967). Bianca (1964) compared two groups of cattle reared at $10^{\circ} \mathrm{C}$ and $27^{\circ} \mathrm{C}$. A $10^{\circ} \mathrm{C}$ temperature is the optimum for cattle, while $27^{\circ} \mathrm{C}$ presents a considerable heat load for the cattle which impairs growth. Kovalčiková and Kovalčik (1974) emphasized that the response of cattle to heat arose relatively quickly even at temperatures which human beings felt as cold. A serious consequence of high temperatures is a general hypofunction of the anterior lobe of the pituitary gland. Insufficient secretion of gonadotropins (FSH and LH) could lead to an inadequate production of progesteron and estrogen which might result in various problems in reproduction. The growth rate was found to decrease under temperatures around $24{ }^{\circ} \mathrm{C}$ and stopped completely in an environment of $29-32^{\circ} \mathrm{C}$.

Evaporation through the skin is one of the particular mechanisms which are significant for thermoregulation of cattle under higher ambient temperatures. Skin evaporation increases four times under temperatures ranging between $15.5^{\circ} \mathrm{C}$ and $26.5^{\circ} \mathrm{C}$. At a temperature of about $34{ }^{\circ} \mathrm{C}$, approximately $26 \%$ of heat losses are due to skin evaporation. If the pressure of water vapours in ambient air is high, the hair cover absorbs the humid air and retards heat loss from the body surface by convection (Sainsbury 1967).

The Czechoslovak standard ON 734516 recommends a temperature not exceeding $22^{\circ} \mathrm{C}$ and maximal relative humidity $75 \%$ for loose housing of heifers during the summer. Under this situation the value of the pressure of water vapours in the ambient air is $14.6 \mathrm{~mm}$ of the $\mathrm{Hg}$ column, i.e. 1959.8 $\mathrm{Pa}$. Szép (1962) reported that the atmosphere became sultry in sheds when this values reached $14.08 \mathrm{~mm} \mathrm{Hg}$, i.e. $1877.1 \mathrm{~Pa}$.

In the present study, various microclimatic situations are analyzed during the summer season under large-scale conditions of housing of heifers in relation to the effect of the ambient temperature and humidity on the housed animals. The share of unfavourable relationships has also been taken into consideration, i.e. the high pressure of water vapours in the ambient air under higher temperatures during the summer season.

\section{Materials and Methods}

The dimensions of the ground plan of the large-scale shed for 1210 heifers in Krákorice are $73.2 \times 84.4 \mathrm{~m}$. The technology of housing is divided into two parts: the front part measures $30.0 \times$ $\times 73.2 \mathrm{~m}$ with grated floor for housing heifers in boxes; heifers of the age from 4.5 to 12 months are housed here. The back part of the shed measures $54.4 \times 73.2 \mathrm{~m}$ and houses heifers of the age from 12 to 18 months in boxes with an elevated bed and central catchpit with mechanical removal of excrements. Overhead conveyors in both parts of the shed are used for feeding. The mangers under the conveyors are situated on ground level. The shed is ventilated with fans installed in the roof-ceiling mantle in five rows; the middle row and the two outer rows have 12 fans removing air from the shed, and the two inner rows with 10 fans bringing the air inside. The inlet ventilators are equipped with deflectors regulating the incoming air so that it does not directly affect the housed animals. During the summer the windows and doors in the outer walls are opened to improve ventilation. In the roof of the ceiling mantle above the transverse corridor and above the mangers, 54 lens-shaped skylights are situated which, together with windows in the upper part of the outer walls, ensure better illumination of the shed.

Ambient temperature and humidity were recorded using thermohygrographs on two positions on the shed diagonals situated on the boundary between the front and the back parts of the shed and in the last third of the back part.

Investigations were carried out from May to September 1986. At the same time, the temperature and humidity of the outside air were registered at the meteorological station of the Czech Hydrometeorological Institute Ostrava in Paseka, localized approximately $2-3 \mathrm{~km}$ in air line from the large-scale shed where the heifers were housed.

The registration tapes were processed in such a way that over the whole investigated period, 
the duration of the particular ranges of temperatures and humidities of the air in the shed was expressed in per cent. The ranges of these two microclimatic factors were selected with respect to the standard ON 73 4516. The ambient temperatures were selected in the following ranges: $6^{\circ} \mathrm{C}, 6^{\circ} \mathrm{C}-12{ }^{\circ} \mathrm{C}, 12{ }^{\circ} \mathrm{C}-22{ }^{\circ} \mathrm{C}$ and above $22^{\circ} \mathrm{C}$. In the summer period, temperatures between $6{ }^{\circ} \mathrm{C}$ and $22{ }^{\circ} \mathrm{C}$ were found to be favourable to optimum. For relative humidity, the ranges of below $75 \%$, from $75 \%$ to $85 \%$, and above $85 \%$ were selected.

Three characteristic macroclimatic situations were determined in the summer period according to the curves of temperature and humidity of the outside air. The first situation represents the cold and rainy summer period from May 29 to June 1,1986 with an average temperature of $10.90^{\circ} \mathrm{C}$ and relative humidity $80.39 \%$. The second situation represents pleasant warm summer weather from May 26 to May 28, 1986 with average diurnal temperatures of $17.95^{\circ} \mathrm{C}$ and relative humidity $66.44 \%$. The third situation represents a hot summer period from July 28 to August 3, 1986 with an average diurnal temperature of $22.01{ }^{\circ} \mathrm{C}$ and relative humidity $63.30 \%$.

In these three typical situations of the macroclimate, the two-hour values of both air temperature and humidity were combined, read from the registration tapes of the same time intervals. The combination of both values was classified into three possible microclimatic situations, i.e. cold, thermal and humidity optimum, and sultry heat. Under temperatures above $17^{\circ} \mathrm{C}$, when the value of $14.1 \mathrm{~mm} \mathrm{Hg}$ of water vapour pressure in the ambient air (i.e. $1879.8 \mathrm{~Pa}$ ) was exceeded, the heat and humidity regime was defined as sultry atmosphere. The cold situation was expressed in temperatures lower than $6^{\circ} \mathrm{C}$ under any relative humidity, or in temperatures between $6{ }^{\circ} \mathrm{C}$ and $17^{\circ} \mathrm{C}$ and relative humidity above $85 \%$. The optimal heat and humidity regime were temperatures between $6.0^{\circ} \mathrm{C}$ and $17.0^{\circ} \mathrm{C}$ and relative humidity lower than $85 \%$, or temperatures higher than $17.0^{\circ} \mathrm{C}$ and pressure of water vapours lower than $14.1 \mathrm{~mm} \mathrm{Hg}$, i.e. $1879.8 \mathrm{~Pa}$.

The three selected typical situations of summer macroclimate were plotted also graphically using the method of the so-called "average day". In this way the dynamics of air temperatures and humidities in the shed were expressed in dependence on the outside air temperature and humidity within 24 hours under the given macroclimate. The dependence between the temperature and humidity of the air in the barn and that of the outside air was evaluated also statistically using the correlation coefficient.

\section{Results}

Results are given in Tabs. 1, 2, 3 and in graphs Nos. 1, 2 and 3. Tab. 1 shows the ambient temperature in the shed during the entire summer period; the temperatures ranged between $12{ }^{\circ} \mathrm{C}$ and $22^{\circ} \mathrm{C}$ over $54.22 \%$ (and/or $75.92 \%$ ) of the period investigated and they exceeded the maximally admissible value of $22{ }^{\circ} \mathrm{C}$ only in $23.50 \%$ (and/or $45.78 \%$ ). Relative air humidity was lower than $75 \%$ over $49.06 \%$ (and /or $66.62 \%$ ) of the period, and it ranged between 75 and $85 \%$ over $26.81 \%$ (and/or $49.59 \%$ ). Only in $1.35 \%$ (and/or $6.57 \%$ ) of this period did relative air humidity exceed the value of $85 \%$.

Table 1

Relatove frequency of occurrence of ambient temperature and humidity in the large-scale shed in values within the selected range during summer

\begin{tabular}{|c|c|c|c|c|c|c|c|c|c|}
\hline \multirow{3}{*}{ Period } & \multicolumn{9}{|c|}{ Front half } \\
\hline & \multicolumn{5}{|c|}{ Air temperature ${ }^{\circ} \mathrm{C}$} & \multicolumn{4}{|c|}{ Air humidity $\%$} \\
\hline & $<6$ & $6-12$ & $12-22$ & $22<$ & $\Sigma$ & $<75$ & $75-85$ & $85<$ & $\boldsymbol{\Sigma}$ \\
\hline $\begin{array}{l}\text { Hours } \\
\%\end{array}$ & $\begin{array}{l}0 \\
0\end{array}$ & $\begin{array}{l}0 \\
0\end{array}$ & $\begin{array}{l}1773 \\
54.22\end{array}$ & $\begin{array}{l}1497 \\
45 \cdot 78\end{array}$ & $\begin{array}{c}3270 \\
100\end{array}$ & $\begin{array}{l}2032 \\
49.06\end{array}$ & $\begin{array}{l}2054 \\
49.59\end{array}$ & $\begin{array}{r}56 \\
1.35\end{array}$ & $\begin{array}{c}4142 \\
100\end{array}$ \\
\hline & \multicolumn{9}{|c|}{ Back half } \\
\hline $\begin{array}{l}\text { Hours } \\
\%\end{array}$ & $\begin{array}{l}0 \\
0\end{array}$ & $\begin{array}{r}19 \\
0.58\end{array}$ & $\begin{array}{l}2497 \\
75.92\end{array}$ & $\begin{array}{c}773 \\
23.50\end{array}$ & $\begin{array}{c}3289 \\
100\end{array}$ & $\begin{array}{l}2453 \\
66.62\end{array}$ & $\begin{array}{c}987 \\
26.81\end{array}$ & $\begin{array}{l}242 \\
6.57\end{array}$ & $\begin{array}{c}3682 \\
100\end{array}$ \\
\hline
\end{tabular}


Table 2

Percentage of duration of the period during which the animals were kept in the large-scale shed in a cold, optimum and sultry regime of air temperature and humidity during a cold and rainy (I), pleasant and warm (II) and hot summer (III) average day

\begin{tabular}{|c|c|c|c|c|c|c|c|c|}
\hline \multirow[b]{2}{*}{$\begin{array}{c}\text { Period of } \\
\text { average day }\end{array}$} & \multicolumn{2}{|c|}{ Outside } & \multicolumn{3}{|c|}{ Front half } & \multicolumn{3}{|c|}{ Back Half } \\
\hline & $\begin{array}{l}\text { average } \\
t_{e}{ }^{\circ} \mathrm{C}\end{array}$ & $\begin{array}{l}\text { average } \\
\mathrm{Rv}_{\mathrm{e}} \%\end{array}$ & cold & optimum & $\begin{array}{c}\text { (Pa) } \\
\text { sultry } \\
\text { (mm Hg) }\end{array}$ & cold & optimum & $\begin{array}{c}(\mathrm{Pa}) \\
\text { sultry } \\
(\mathrm{mm} \mathrm{Hg})\end{array}$ \\
\hline I. & 10.90 & 80.39 & 0 & 78.72 & 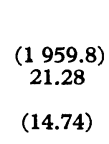 & 0 & 93.88 & $\begin{array}{c}(2003.8) \\
6.12 \\
(15.03)\end{array}$ \\
\hline II. & 17.95 & 66.44 & 0 & 21.88 & $\begin{array}{c}(2146.5) \\
78.12 \\
(16.10)\end{array}$ & 0 & 48.48 & $\begin{array}{c}(2167.8) \\
51.52 \\
(16.26)\end{array}$ \\
\hline III. & 22.01 & 63.30 & 0 & 47.66 & $\begin{array}{c}(2110.5) \\
52.34 \\
(15.83)\end{array}$ & 0 & 41.18 & $\begin{array}{c}(2146.5) \\
58.82 \\
(16.10)\end{array}$ \\
\hline
\end{tabular}

Tab. 2 shows that sultry conditions arise to a greater extent in macroclimatic conditions where the average diurnal temperatures are above $18{ }^{\circ} \mathrm{C}$ (or above $22^{\circ} \mathrm{C}$ ) and we can speak of pleasant warm (or hot) summer weather. This sultry condition was observed in $52.34 \%$ (and/or $58.82 \%$ ) under an average outside temperature of $22.01{ }^{\circ} \mathrm{C}$, the average pressure of water vapours being 15.83 or $16.10 \mathrm{~mm} \mathrm{Hg}$ (i.e. $2110.5 \mathrm{~Pa}$ and $2146.5 \mathrm{~Pa}$, respectively). When the average oustide temperature was $17.95^{\circ} \mathrm{C}$, this condition was observed over $78.12 \%$ (or $51.52 \%$ ) of the entire period of investigations, the average pressures of water vapours being 16.10 or $16.26 \mathrm{~mm} \mathrm{Hg}$ (i.e. 2146.5 and $2167.8 \mathrm{~Pa}$, respectively).

Under the combined effect of temperatures and air humidity in the summer period, no condition of cold appeared, as had been expected, even though the temperatures ranged between $6{ }^{\circ} \mathrm{C}$ and $12{ }^{\circ} \mathrm{C}$ in $0.58 \%$ of the period investigated. This would mean that these temperatures were not connected with values of air humidity above $85 \%$. Such high values of relative air humidity were observed only in $1.35 \%$ (and /or $6.57 \%$ ) of the period investigated (Tab. 1).

Finally, Tab. 2 shows that when the average diurnal outside temperature is $10.90{ }^{\circ} \mathrm{C}$, there is an optimal heat and humidity regime in the front and back parts of the shed, i. e. in $78.72 \%$ and $93.88 \%$, respectively, of the period under investigation.

A detailed analysis performed in the hot summer period in the front part of the barn revealed that a sultry microclimate did not occur immediately after the outside temperatures shifted from the range of $10-20^{\circ} \mathrm{C}$ to $20-30^{\circ} \mathrm{C}$. Sultriness did not occur until the second day of the high outside temperatures ranging between 20 and $30^{\circ} \mathrm{C}$, i. e. on July 29,1986 , for 2 hours at about 8.00 p. m.; sultriness occurred again on the third day, i. e. 30 July, 1989, for about 6 hours between 4.00 and 12.00 p. m.; on the 4 th day, i. e. 31 July 1986, from 10.00 a. m. continuously until $2.00 \mathrm{p}$. m. On August 2, 1986, sultriness was observed for 4 hours with interruptions from 4.00 to $8.00 \mathrm{p}$. m., from 8.00 to $10.00 \mathrm{p}$. m. and from midnight until the last (i. e. 7th) day of high outside temperatures, that is until August 3, 1986. However, in the front part of the shed, sultriness lasted continuously two days more, i. e. until $6.00 \mathrm{p}$. m. on August 5, 1986 even after the outside temperatures decreased to $20^{\circ} \mathrm{C}$. At about 6.00 a. m. on August 6, 1986, the 
Table 3

Statistical characteristics $\left(\bar{x} s^{2}\right)$ and coefficient of correlation $(r)$ of ambient temperature (T $\left.{ }^{\circ} \mathrm{C}\right)$ and humidity $(R V \%)$ in the front $(P / 2)$ and back $(Z / 2)$ halves of the large-scale shen and outside the shed during cold and rainy (I), plesant and warm (II) and hot summer (III) average day.

\begin{tabular}{|c|c|c|c|c|c|c|c|c|c|c|}
\hline & \multicolumn{3}{|c|}{ I. } & \multicolumn{3}{|c|}{ II. } & \multicolumn{3}{|c|}{ III. } \\
\hline & & $\mathbf{P} / 2$ & $Z / 2$ & outside & $\mathrm{P} / 2$ & $Z / 2$ & outside & $\mathrm{P} / 2$ & $Z / 2$ & outside \\
\hline $\begin{array}{r}\mathbf{T}{ }^{\circ} \mathbf{C} \\
\mathbf{R v} \%\end{array}$ & $\begin{array}{l}\bar{x} \\
s^{2} \\
r \\
\bar{x} \\
s^{2} \\
r\end{array}$ & $\begin{array}{c}19.47 \\
0.321 \\
+0.4725 \\
75.80 \\
1.64 \\
-0.2454\end{array}$ & $\begin{array}{c}18.02 \\
0.482 \\
+0.3684 \\
72.20 \\
1.58 \\
+0.1449\end{array}$ & $\begin{array}{c}10.90 \\
1.060 \\
- \\
80.39 \\
18.50 \\
-\end{array}$ & $\begin{array}{c}23.84 \\
2.80 \\
+0.4917 \\
69.04 \\
6.33 \\
+0.6071\end{array}$ & $\begin{array}{c}22.48 \\
4.07 \\
+0.9369 \\
68.02 \\
21.80 \\
-0.2822\end{array}$ & $\begin{array}{c}17.95 \\
10.50 \\
- \\
66.44 \\
55.70 \\
-\end{array}$ & $\begin{array}{c}23.28 \\
4.25 \\
+0.9745 \\
67.89 \\
37.60 \\
+0.9754\end{array}$ & $\begin{array}{c}22.27 \\
4.69 \\
+0.9859 \\
73.37 \\
36.50 \\
+0.6679\end{array}$ & $\begin{array}{c}22.01 \\
18.90 \\
- \\
63.30 \\
169.00 \\
-\end{array}$ \\
\hline
\end{tabular}

outside temperature finally decreased to $15^{\circ} \mathrm{C}$, and then again increased until it reached $20-30^{\circ} \mathrm{C}$ again on August 11,1986 . Sultriness lasted continuously in the front part of the shed from August 7-13, 1986, in the period between August 13 and 16, 1986 it appeared only twice in 2 to 4-hour intervals, and again from 8.00 a. m. on August 16 till 8.00 a. m. on August 20, 1986. On August 17, 1986 the outside air temperatures rapidly decreased to a range between 20 and $10{ }^{\circ} \mathrm{C}$ which was maintained until the end of August, when short intervals of sultriness in the front part of the shed were reported only between $2.00 \mathrm{a} . \mathrm{m}$. and $2.00 \mathrm{p} . \mathrm{m}$. until August 26, 1986. From 6.00 p. m. on August 26, 1986, a sultry atmosphere was recorded until 2.00 a. m. on August 29, 1986.

In the back part of the shed, sultriness did not occur when the outside air temperatures fell to a range from 10 to $20^{\circ} \mathrm{C}$ on August 20, 1986 at $6.00 \mathrm{a}$. m. until the end of August. Only on August 27, 1986, sultriness was recorded for 2 hours from 4.00 to $6.00 \mathrm{p}$. $\mathrm{m}$.

This analysis shows that the occurrence and duration of the sultry condition is connected with higher outside air temperatures, i. e. $20-30^{\circ} \mathrm{C}$, and that this condition is more frequent in the front part of the barn even when the outside temperatures range between 10 and $20^{\circ} \mathrm{C}$.

Fig. 1-3 show the dependence of the dynamics of curves of the air temperature and humidity in the shed on those outside the shed. This dependence is the most marked under the macroclimatic situation of $22.01{ }^{\circ} \mathrm{C}$ (Fig. 3). In the other two macroclimatic summer situations (average air temperatures $17.95^{\circ} \mathrm{C}$ and $10.90^{\circ} \mathrm{C}$, respectively) the curves expressing air temperature are much more similar (Fig. 1 and 2).

Tab. 3 shows the statistical dependence between the air temperature and humidity in the shed and outside using the correlative coefficient. It shows that the correlation between the air temperature and humidity in the shed and outside is highly significant particularly during the hot summer period $(r=0.9745 ; 0.9859$; $0.9754 ; 0.6679)$. In this period the ventilation in the shed was good, all doors were open as well as the windows on the outer walls.

The curve of the air temperature inside the shed in the hot summer period (Fig. 3) confirms that the highest average temperature was $26^{\circ} \mathrm{C}$ and that it was by $2{ }^{\circ} \mathrm{C}$ lower that the outside air temperature, proving that thermal insulation of the ceiling roof mantle of the shed was good.

Fig. 2 gives the curves of air temperatures and humidity under an average outside air temperature of $17.95^{\circ} \mathrm{C}$; the course of the curves is less marked, particularly that of relative air humidity in the back part of the shed from $10.00 \mathrm{a} . \mathrm{m}$. till 12.00 p. m. Tab. 3 also shows that the dependence of ambient temperature in 

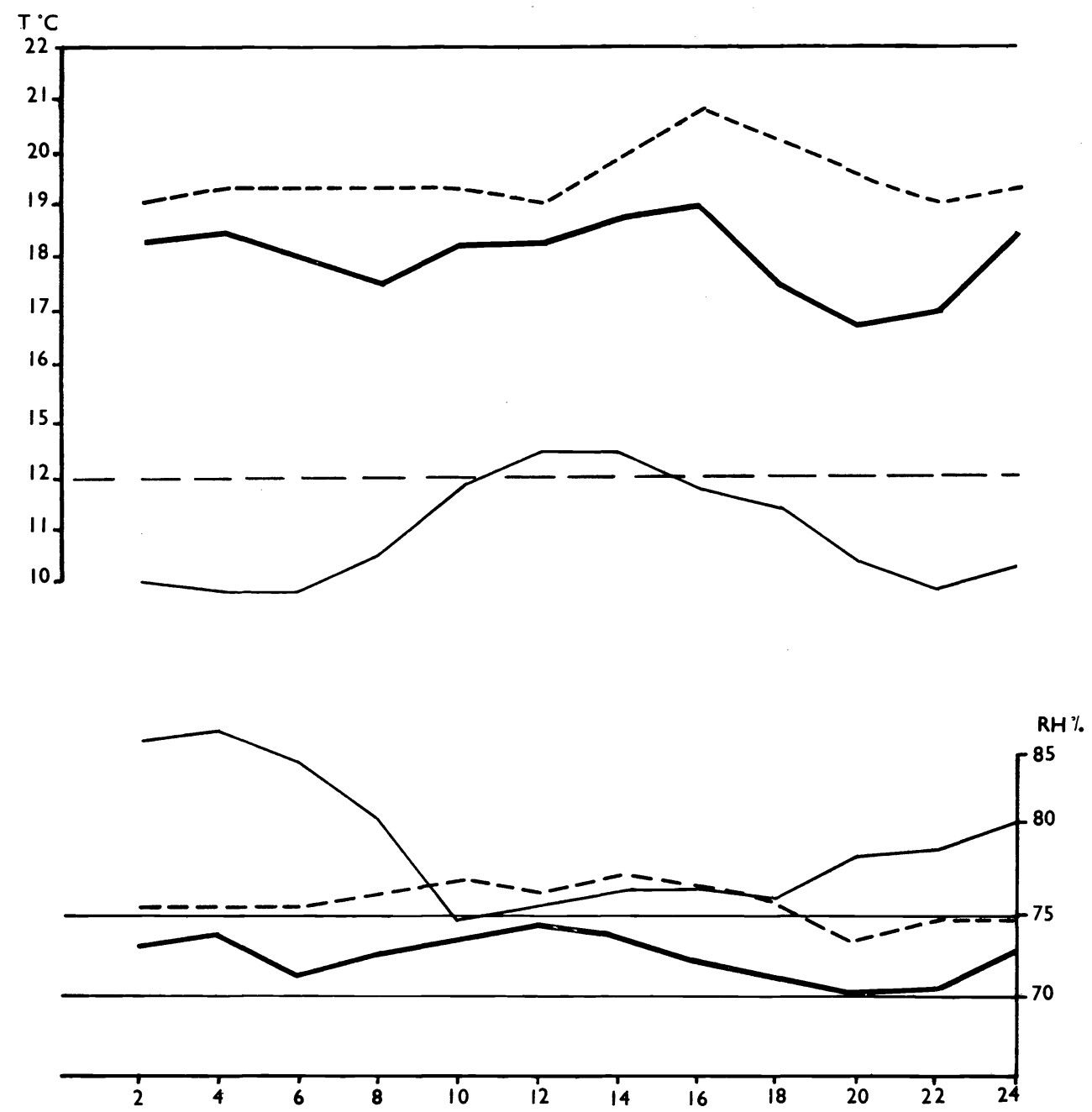

HOURS OF THE DAY

Fig. 1. Dynamics of ambient temperature and humidity in the large-scale shed during cold and rainy summer average day $\left(T=10.90^{\circ} \mathrm{C}: R H=80.39 \%\right)$

Legend: - _ - - - front half of shed

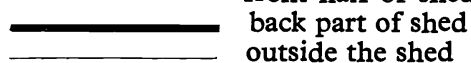

the shed on the temperature of the outside air (i. e. average $17.95^{\circ} \mathrm{C}$ ) during the warm summer period is highly significant only in the back part of the shed $(r=$ $=0.9369$ ), the correlations between the relative air humidity being negative and statistically insignificant $(\mathrm{r}=-0.2822)$.

In Fig. 3 the mutual position of the curves for ambient temperature and humidity is given; with good ventilation the position of the curve is mirror-like when the average outside temperature is $22.01^{\circ} \mathrm{C}$ and relative air humidity $63.30 \%$. 


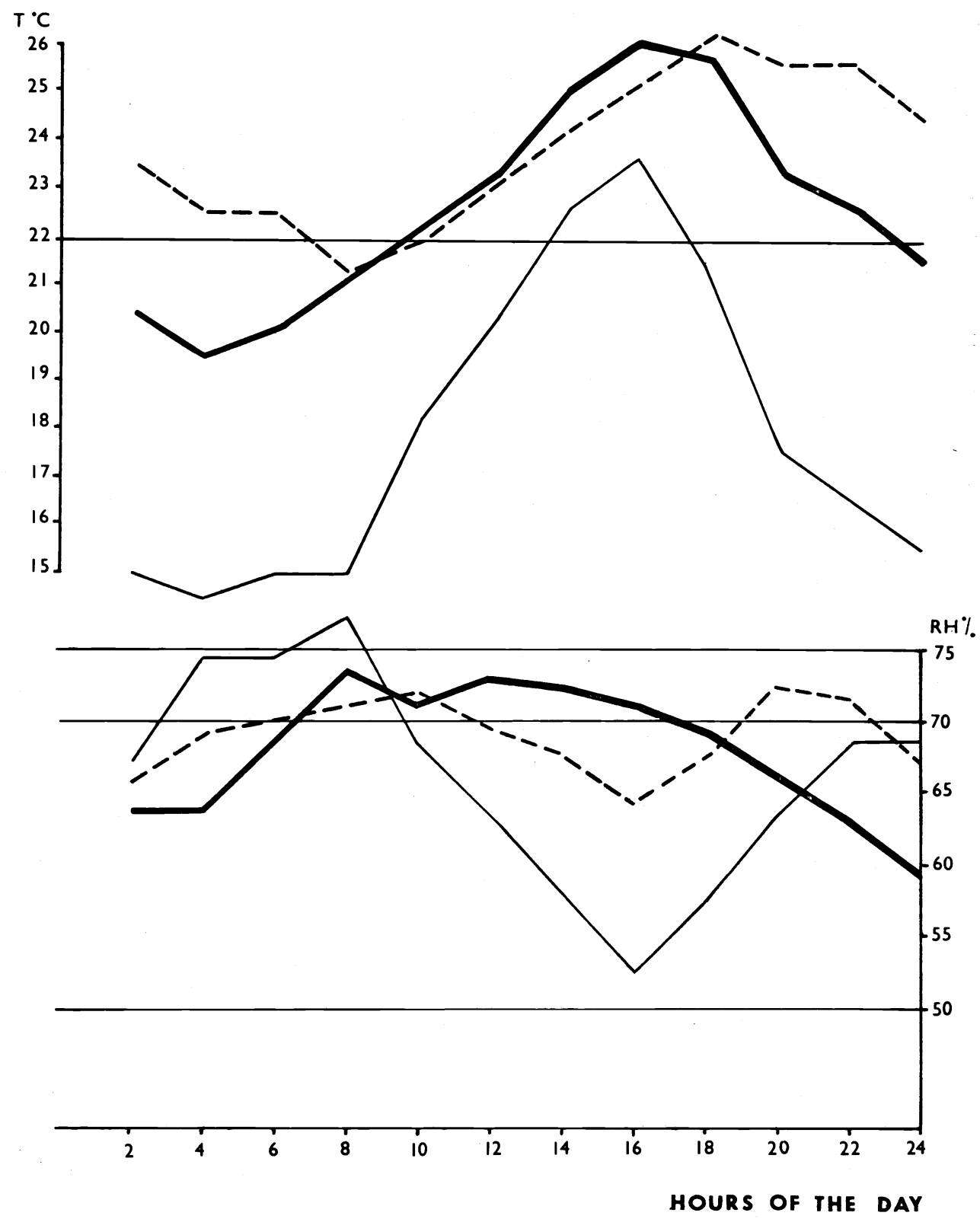

Fig. 2. Dynamics of ambient temperature and humidity in the large-scale shed during pleasant and warm summer average day $\left(T=17.95^{\circ} \mathrm{C} ; R H=66.44 \%\right)$

Legend: $-\ldots$ - - front half of shed

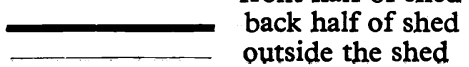



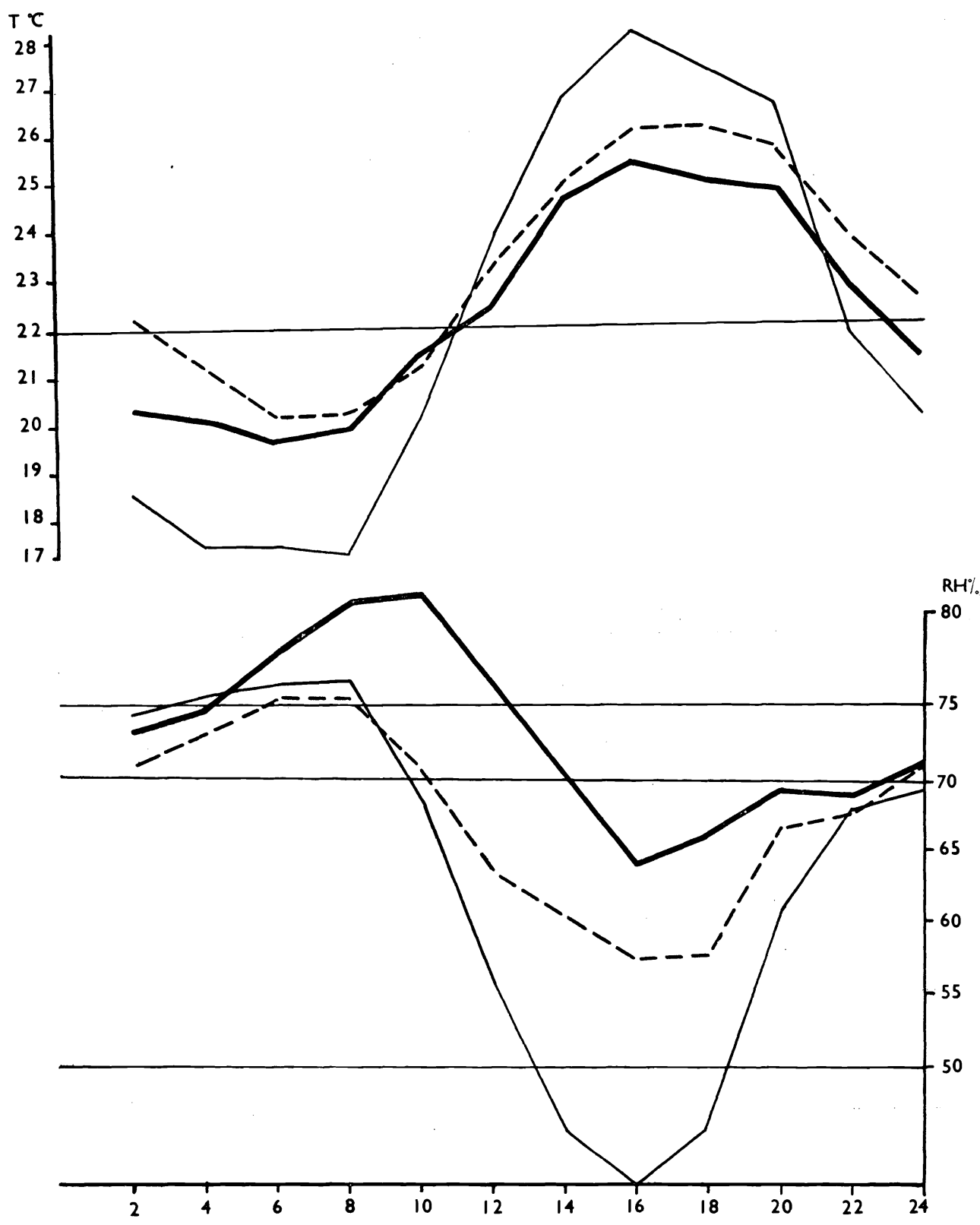

HOURS OF THE DAY

Fig. 3. Dynamics of ambient temperature and humidity in the large-scale shed during a hot summer average day $\left(T=22.01{ }^{\circ} \mathrm{C} ; R H=63.30 \%\right)$

Legend: _ _ _ _ - front half of shed back half of shed outside the shed 
Fig. 2 shows that this mirror-like position of the curve for humidity in relation the curve for heat is more evident in the front part of the shed when the outside air temperature is $17.95 \%$ and relative air humidity $66.44 \%$. In Fig. 1 the mirror-like course of the two curves disappeared entirely when the outside temperature was $10.90{ }^{\circ} \mathrm{C}$ and the relative air humidity $80.39 \%$.

From Tab. 3 we can see that the dependence between temperature and humidity in the shed and outside is not statistically significant in both parts of the shed during cold and rainy summer weather; this was evident particularly for relative humidity $(r=-0.2454 ; 0.1449)$ and was low and only slightly significant for the ambient temperature $(\mathrm{r}=0.4725 ; 0.3684)$.

During pleasant summer weather as well as during cold and rainy weather, ventilation of the shed through doors and windows was reduced and was done chiefly with ventilation fans installed in the roof-ceiling of the shed. The thermal and humidity regime in the shed was regulated by automatic ventilation in dependence on the indicator temperature of the regulating sensor.

\section{Discussion}

Analyses of results given in Tab. 1 showed that the microclimate, i. e. the duration of the optimal temperature and relative humidity, during the summer was more favourable in the back half of the shed. Relative humidity in the front and back halves of the shed exceeded $75 \%$ (and/or $85 \%$ ) in $51 \%$ and $33 \%$, respectively, of the period investigated. If, in addition, the temperature rose above $22^{\circ} \mathrm{C}$, or $17^{\circ} \mathrm{C}$, the pressure of water vapours could increase to more than $14.1 \mathrm{~mm}$ $\mathrm{Hg}$ (i. e. $1879.8 \mathrm{~Pa}$ ), inducing sultriness (Szép 1962). Curtis (1987) reported that cow's milk production need not decrease as a consequence of thermal stress under a temperature of $29^{\circ} \mathrm{C}$ if relative humidity is maintained at $40 \%$, i. e. pressure of water vapours $11.9 \mathrm{~mm} \mathrm{Hg}$ (i. e. $1586.5 \mathrm{~Pa}$ ). If relative humidity increases to $90 \%$ (pressure of water vapours $26.8 \mathrm{~mm} \mathrm{Hg}$, i. e. $3573.0 \mathrm{~Pa}$ ), milk production decreases by $20-30 \%$. The marginal value of pressure of water vapours bringing about sultriness was found to be $14.1 \mathrm{~mm} \mathrm{Hg}$ (i. e. $1879.8 \mathrm{~Pa}$ ); in this respect the average values of 15.83 to $16.26 \mathrm{~mm} \mathrm{Hg}$ (i. e. 2110.5 to $2167.8 \mathrm{~Pa}$ ) are values slightly exceeding the value critical for sultriness to occur. A longer effect of these values might disturb the thermoregulation abilities of the animals when releasing heat by skin osmosis and pseudotranspiration (Sainsbury 1967) and have a negative effect on body increments or reproductive ability of the housed animals (Kovalčiková and Kovalčik 1974).

The state of sultriness is limited by the ambient temperature and cannot occur until the temperature reaches $16-17^{\circ} \mathrm{C}$, when the pressure of water vapours is $14.1 \mathrm{~mm} \mathrm{Hg}$ (i. e. $1879.8 \mathrm{~Pa}$ ) and relative air humidity $100-97 \%$. Sultriness is brought about at $19{ }^{\circ} \mathrm{C}, 24^{\circ} \mathrm{C}, 30^{\circ} \mathrm{C}$ and $32^{\circ} \mathrm{C}$ when relative air humidity exceeds $85 \%, 65 \%, 50 \%, 44 \%$ and $39 \%$, respectively. The combination of ambient temperature and pressure of water vapours in the bioclimatology of cattle resulted in a definition of strain of different intensity, expressed by the thermal and humidity index. For Holstein dairy cows this index is characterized as lower than 23.5 (i. e. between 23.5 and 25 ) and above 26 (i. e. slight to zero, moderate, and heavy strain) (Curtis 1987). If we substitute e. g. $30^{\circ} \mathrm{C}$ (under relative humidity of $38.9 \%$ ) to the respective formula for calculations of this index, then such a situation occurs corresponding to a pressure of water vapours of $12.4 \mathrm{~mm} \mathrm{Hg}$ (i. e. 
$1653.2 \mathrm{~Pa}$ ) and the resulting number of the index is 24.8 what means moderate strain for the high-efficient dairy cow. Under the same temperature, but $44 \%$ relative humidity, and pressure of water vapours $14.1 \mathrm{~mm} \mathrm{Hg}$ (i. e. $1879.8 \mathrm{~Pa}$ ), the resulting number of the index is 15.2, what is approaching the limit of heavy strain. If the temperature is $30^{\circ} \mathrm{C}$ and the relative humidity increases to $66.9 \%$, the number of the index is 26.8 , what is heavy strain for the dairy cows due to the simultaneous effect of temperature and humidity.

In accordance with this conception, Hauptmann et al. (1988) reported that milk production decreased by $25-35 \%$ under $30{ }^{\circ} \mathrm{C}$ temperature and $70 \%$ relative humidity, i. e. when the pressure of water vapours corresponded to $22.26 \mathrm{~mm}$ $\mathrm{Hg}$ (i. e. $2967.7 \mathrm{~Pa}$ ). Milk production decreased to below $20 \%$ under $50 \%$ relative humidity and $15.90 \mathrm{~mm} \mathrm{Hg}$ pressure of water vapours (i. e. $2119.8 \mathrm{~Pa}$ ). Johnson, Vanjonach (cit. Baker et al. 1988) observed that milk production decreased by $4.4 \mathrm{~kg}$ of milk per day per cow when the ambient temperature was $32{ }^{\circ} \mathrm{C}$ and relative humidity increased from $20 \%$ to $40 \%$, i. e. when the pressure of water vapours increased from $7.14 \mathrm{~mm} \mathrm{Hg}$ to $14.28 \mathrm{~mm} \mathrm{Hg}$ (from $951.9 \mathrm{~Pa}$ to $1903.8 \mathrm{~Pa}$ ). Curtis (1987) reported that the milk production of Holstein dairy cows whose daily milk production was $45 \mathrm{~kg}$ decreased under $29.4{ }^{\circ} \mathrm{C}$ and pressure of water vapours $14.63 \mathrm{~mm} \mathrm{Hg}$, i. e. $1950.5 \mathrm{~Pa}$. He calculated this expected decrease by substituting into the respective formula following from an experiment in an air controlled chamber in Missouri. The result corresponds to a decrease of $9.7 \mathrm{~kg}$ of milk a day, i. e. an approximately $20 \%$ decreased production.

Basing on these data, the limiting value for sultriness of $14.1 \mathrm{~mm} \mathrm{Hg}$ (i. e. $1879.8 \mathrm{~Pa}$ ) for dairy cows may be considered to be acceptable under Czechoslovak conditions of cattle efficiency.

Under the given technology of litter-free housing of heifers in boxes with grated floor and in boxes with uncovered catchpit the duration of sultriness during the summer is dependent on the intensity of ventilation of the barn and on the removal of excrements or liquid manure from the barn. The construction of the building itself, as regards thermal insulation of the roof and ceiling mantle, is very good; temperatures in the shed were maintained about $2{ }^{\circ} \mathrm{C}$ lower than were the average temperatures of the hot summer outside air (Graph 3). Fear of the possible glasshouse effect induced by installing glass lens into the roof ceiling mantle proved to be groundless in all the three macroclimatic situations which were analyzed. (Figs. 1, 2, 3).

With regard to results presented in Tab. 1 it is possible to evaluate the course of temperatures and humidities of air in the barn in the summer period investigated as satisfactory; most of the time the animals were housed in the zone of temperatures between 12 and $22{ }^{\circ} \mathrm{C}$, i. e. 54.22 or $75.92 \%$ of the entire period of investigations. However, the effects of the ambient temperature cannot be evaluated without taking into consideration also the air humidity at the same time. Fišer et al. (1989) reported that sultriness occurred in the front and back parts of the large-scale barn over $35.84 \%$ and $24.03 \%$, respectively of the whole period of investigations. This percentage is relatively very low; along with sultriness, the pressure of water vapours did not greatly exceed the critical limit of $14.1 \mathrm{~mm} \mathrm{Hg}$, i. e. $1879.8 \mathrm{~Pa}$. The pressure of water vapours in the ambient air of the shed in the three selected microclimatic situations exceeded this critical value, on average, only by $2.16 \mathrm{~mm} \mathrm{Hg}$, i. e. by $287.9 \mathrm{~Pa}$ (Tab. 2). Detailed analyses showed that under macroclimatic situations with air temperatures within $20-30^{\circ} \mathrm{C}$, a long effect of sultriness on the housed animals may occur if air ventilation is insufficient. 
In such a case the thermal and humidity regime in the front part of the shed was found to be less favourable than in the back part of the shed during summer.

Explanation of this fact must be based on the evaluation of the ventilation system of the shed for heifer rearing where the exchange of air is ensured with ventilation equipment of equal pressure with fans situated in the roof-ceiling mantle. However, during one control, 14 of the total numer of 56 fans were found to be out of order or had been dismantled; 12 of these 14 had to exchange air in the front part of the shed. Another shortcoming is the noise of the fans when switched on which exceeded $73 \mathrm{~dB}$ for a long time. Recent data have confirmed that noise above $73 \mathrm{~dB}$ disturbs the protein, lipid and carbohydrate metabolism of the heifers (Girina 1986).

In the case of fall-out of electric energy, or during the hot summer period, ambient temperature and humidity can be regulated by opening the windows and doors over the whole east and west outer walls and windows in the north and south walls. During measurements performed on August 21, 1986 when the fans stopped operating due to a fall-out of electric energy, the shed was aerated by opening all the doors and windows. Average ambient temperatures of $17.9^{\circ} \mathrm{C}$ were measured in teh shed, the outside air temperatures being $16.8-17.4^{\circ} \mathrm{C}$; relative humidity in the shed was $65.6 \%$ and outside $57-58 \%$ These data show that the exchange of air in the shed was good. The rate of air flow in the shed corresponded to $0.233 \mathrm{~m} \mathrm{.} \mathrm{s} \mathrm{s}^{-1}$ when the velocity of north-east wind was $0.601 \mathrm{~m} . \mathrm{s}^{-1}$. The content of $\mathrm{CO}_{2}$ in the ambient air in the shed was on average $0.23 \%$ vol. Under this and similar condition the shed becomes a covered shelter for the housed animals and the well-insulated roof and ceiling mantle protects the housed animals against direct insolation, or overheating; the thermal and humidity conditions in the shed become balanced with with those of the outside air. Under the conditions during high summer temperatures of around $30^{\circ} \mathrm{C}$ all the fans of the ventilation system will be running, the occurrence of sultry conditions can be reduced to minimum. The flow of air in the zone of the animals could be increased by removing or regulation the area of the deflectors which control the pressure inlet of air through the fans into the shed. The rate of the air flow increased above $0.3 \mathrm{~m} \mathrm{~s} \mathrm{~s}^{-1}$ has been recommended in the standard ON 734516 to be up to $0.5 \mathrm{~m} \mathrm{.} \mathrm{s}{ }^{-1}$ for the summer period, and $2.0 \mathrm{~m} . \mathrm{s}^{-1}$ when the temperatures exceed $22{ }^{\circ} \mathrm{C}$.

The course of temperatures and humidities in the barn for heifer rearing during the summer period can be improved through better care of the technical condition of the fans and their function and by more frequent removal of sources of humidity form the barn during the day.

\section{Teplotně vlhkostní režim velkokapacitní haly pro odchov jalovic v letním období}

V předložené studii teplotně vlhkostního režimu velkokapacitní haly pro odchov jalovic jsou analyzovány tři makroklimatické situace $\mathrm{v}$ průběhu letního období od května do záŕi 1986. Makroklimatické situace jsou charakterizovány jako chladné letní deštivé období, prŕijemné letní teplé období a horké letní období.

Při analýze tři vybraných makroklimatických situací $\mathrm{v}$ průběhu letního období je posouzen současný účinek teploty a vlhkosti stájového vzduchu na ustájená zvířata vyjádřený jako chlad, teplotně vlhkostní optimum a dusno. Vzájemný vztah 
venkovní a vnitřní stájové teploty a vlhkosti vzduchu je znázorněn graficky jako tzv. průměrný den sledovaného období.

Podle zjištěných výsledků dochází $\mathrm{v}$ hale $\mathrm{k}$ výskytu stavů dusna při průměrných venkovních teplotách $17,95{ }^{\circ} \mathrm{C}$ v $51,52 \%$ resp. $78,12 \%$ doby pobytu zviŕat ve stáji. Optimální vztah teploty a vlhkosti vzduchu byl dosahován z 78,72\% resp. $93,88 \%$ sledované doby při průměrné denní venkovní eplotě vzduchu $10,90{ }^{\circ} \mathrm{C}$. Př̀i prüměrných venkovních teplotách vzduchu $22,01^{\circ} \mathrm{C}$ trvaly stavy dusna $52,34 \%$ resp. $58,82 \%$ sledované doby pobytu zvířat $\mathrm{v}$ hale.

Největši závislost teploty a vlhkosti stájového vzduchu na teplotě a vlhkosti venkovního vzduchu byla $\mathrm{v}$ horkém létě, kdy průměrná teplota venkovního vzduchu odpovídá $22,01{ }^{\circ} \mathrm{C}$ a relativní vlhkost vzduchu $63,30 \%$. Statisticky byla potvrzena vysoká korelační závislost. $\mathrm{V}$ dalších dvou makroklimatických letních situacích při průměrné denní teplotě vzduchu $17,95^{\circ} \mathrm{C}$ a $10,90^{\circ} \mathrm{C}$ je podobnost průběhu křivek vyjádřena výrazněji jen u teploty vzduchu. Statisticky byla potvrzena vysoce významná korelace mezi teplotami vnitřního a vnějšího vzduchu pouze $v$ teplém letním období $\left(17,95^{\circ} \mathrm{C}\right)$ v zadní polovině haly. Průběh křivky stájové vlhkosti vzduchu není vždy shodný s průběhem křivky vlhkosti venkovního vzduchu. To souvisí $\mathrm{s}$ větraností přední a zadní poloviny haly resp. se způsobem odstraňování zdrojů vodních par, tj. výkalů, moče a technologické vody $z$ haly.

\section{Температүрно-влажностный режим большепролетного помещения для содержания телок в летний период}

В представленной работе по температурно-влажностному режиму большепролетного помещения для содержания телок дается анализ трех макроклиматических ситуаций в летний период с мая по сентябрь 1986 г. Макроклиматические ситуации характеризуются как холодная летняя дождливая погода, приятная летняя теплая погода и жаркая летняя погода.

В ходе анализа трех избранных макроклиматических ситуаций в летний период оценивались воздействие температуры и влажности воздүха помещения на содержимые животные, выраженное как холод, оптимальный температурно-влажностный режим и дүхота. Взаимное отношение наружной и внутренней температуры помещения и влажности воздуха приводится в диаграмме в качестве так называемого среднего односуточного дня исследуемого периода.

По полученным результатам в помещении наблюдается дүхота при средней наружной температуре $17,95{ }^{\circ} \mathrm{C}$ в случае $51,52 \%$ или $78,12 \%$ времени пребывания животных в помещении. Оптимального отношения температуры и влажности воздуха было достигнуто в $78,72 \%$ или $93,88 \%$ исследуемого периода при средней сүточной наружной температуре воздуха $10,90{ }^{\circ} \mathrm{C}$. При средней наружной температүре воздуха $22,01{ }^{\circ} \mathrm{C}$ состояние дүхоты длилось $52,34 \%$ или $58,82 \%$ исследуемого периода пребывания животных в помещении.

Самая большая зависимость температуры и влажности воздүха помещения от температуры и влажности наружного воздуха наблюдалась в жаркую летнюю погоду, когда средняя температура наружного воздүха достигала $22,01^{\circ} \mathrm{C}$ и относительная влажность воздүха - $63,30 \%$. Статистически была установлена высокая корреляционная зависи- 
мость. В ходе последующих двух макроклиматических летних ситуаций при средней сүточной температуре воздүха $17,95{ }^{\circ} \mathrm{C}$ и $10,90{ }^{\circ} \mathrm{C}$ сходство кривых выражено более ярко лишь у температуры воздуха. Статистически была установлена весьма значительная корреляция между температурой внутреннего и наружного воздуха лишь в теплую летнюю погоду $\left(17,9^{\circ}\right)$ в задней половине помещения. Ход кривой влажности помещения не всегда совпадает с кривой влажности наружного воздуха. Это связано с вентиляцией передней и задней половин помещения или со способом удаления источников водяного пара, т. е. экскрементов, мочи и технологической воды из помещения.

\section{References}

BAKER, C. C.-COPPOCK, C. E.-LANHAM, J. K.-NAVE, D. H.-LABORE, J. M.BRASINGTON, C. F.-STERMEN, R. A.: Chilled drinking water effects in lactating cows in summer. J. of Dairy Sci., 71, 1988, 10: 2 699-2 708.

BIANCA, W.: Haustier und Klima. Schweizer Archiv für Tierheilkunde, 106, 1964. 9: 535-557.

CURTIS, S. E.: Environmental management in animal agriculture. Iowa State University Press, AMES, 1987, p. 409, Sec. printing.

FIŠER, A.-MÂHRLOVÁ, O.-HÂJKOVÁ, J.: Bioklimatologické zhodnocení teplotně vlhkostního režimu velkokapacitní haly monobloku pro odchov jalovic $\mathrm{v}$ letním a zimním období. Veterinár̆ství 39, 1989, 7: 319-321.

GIRINA, V. P.: Izmenenie obmennych processov u netelej pod vlijaniem proizvodstvennogo šuma. Veterinarija, 1986, 2: 32-34.

HAUPTMANN, J.-TOUFAR, O.-DOLEJŠ, J.-MUSIL, J.: Vliv vyšších teplot na užitkovost dojnic. Náš chovatel, 48, 1988, 9: 385-387.

KOVALČIKOVÁ, M.-KOVALČIK, K.: Adaptácia a stres $\mathrm{v}$ chove hospodárskych zvierat. Príroda, Bratislava, 1974, p. 206.

SAINSBURY, D.: Logement et la Santé des Animaux. Technipel, Paris, 1967, p. 183.

SEMENJUTA, A. T.-KOLESNIKOV, I. K.: Gazoenergetičeskij obmen u krupnogo rogatogo skota. Veterinarija, 1986, 6: $16-17$.

SZÉP, J.: Összehásonlíto mikroklimavizsagálatok szarvasmarhaistállokban. Agrártud. Egmat. Mezögazdaságtud. Kar. Közl., 1962: 29-72.

ON 73 4516: Projektování staveb pro chov skotu. 1979, Praha, MZVž, p. 41. 